\title{
Peptide Uptake in Candida albicans
}

\author{
By MEGAN B. DAVIES $\dagger$ \\ Sub-department of Chemical Microbiology, Biochemistry Department, \\ University of Cambridge, Cambridge CB2 $1 Q W$
}

(Received 7 January 1980; revised 3 June 1980)

Transport of radioactively labelled peptides has been used to characterize a common transport system for di- and tripeptides in Candida albicans. This permease is energy-dependent and has a requirement for $L$-amino acid residues, an $\alpha$-linkage between residues and a free amino terminus. Transport was followed by the accumulation inside the cell of intact peptides and component amino acids. After transport of glycyl-[U-14 C]phenylalanine the radioactive material was accumulated inside the cell and subsequently leaked into the medium under certain conditions.

\section{INTRODUCTION}

The transport of peptides by micro-organisms has been studied in bacteria, in particular in Escherichia coli (Payne \& Gilvarg, 1978), in the yeasts Saccharomyces cerevisiae (Becker \& Naider, 1977; Marder et al., 1977; Nisbet \& Payne, 1979 a) and Candida albicans (Lichliter et al., 1976; Logan et al., 1979) and in the fungus Neurospora crassa (Wolfinbarger \& Marzluf, 1974). In E. coli there is a dipeptide permease and at least one oligopeptide permease (also capable of transporting dipeptides), in $S$. cerevisiae di- and tripeptides share a common transport system and in $N$. crassa only oligopeptides are transported, dipeptides being hydrolysed before being transported into the cell as amino acids.

The dipeptide antibiotic bacilysin enters the cells of sensitive organisms through the peptide transport system (Kenig et al., 1976) and these carriers have been exploited in the development of the antibacterial agent alafosfalin (Allen et al., 1978). The structural requirements of the permeases in $E$. coli have been defined; these include the nature of any substitution in the amino or carboxyl termini (Payne, 1974; Payne \& Gilvarg, 1968a), the stereospecificity of the residues (Levine \& Simmonds, 1962), the peptide bond (Payne, $1972 a, b$ ), the chain length (Payne \& Gilvarg, 1968b) and the nature of the amino acid residues. The importance of several of these elements in peptide transport has also been investigated in $S$. cerevisiae and $C$. albicans with a view to designing new antifungal agents (Nisbet \& Payne, 1979a; Logan et al., 1979). The results reported in this paper provide evidence for a common peptide permease for di- and tripeptides in C. albicans. Some of its structural requirements and the fate of the amino acids transported into the cells as peptides are described.

\section{METHODS}

Organism and culture conditions. Candida albicans strain 6406, obtained from the Mycological Reference Laboratory, London School of Hygiene and Tropical Medicine, was used in this study. It was maintained on yeast morphology agar (Difco) slopes. Cultures were grown overnight in yeast nitrogen base (YNB, Difco, $\left.6.7 \mathrm{~g} \mathrm{1}^{-1}\right)$ containing $2 \%(\mathrm{w} / \mathrm{v})$ glucose and these were used to inoculate flasks containing YNB supplemented with $2 \%(\mathrm{w} / \mathrm{v})$ Bacto-peptone (Difco) and $2 \%(\mathrm{w} / \mathrm{v})$ glucose. Cultures were grown at $37^{\circ} \mathrm{C}$

$\dagger$ Present address: Department of Microbiology, New York University School of Medicine, New York, N.Y. 10016, U.S.A. 
in an orbital incubator (Gallenkamp) until the density reached $0.2 \mathrm{mg}$ dry wt $\mathrm{ml}^{-1}$ when the cells were harvested by centrifugation and resuspended at $4 \mathrm{mg} \mathrm{ml}^{-1}$ in $0 \cdot 1 \mathrm{M}-\mathrm{Na}_{2} \mathrm{HPO}_{4} /$ citric acid buffer, $\mathrm{pH} 5 \cdot 0$. The cell density was routinely measured turbidimetrically at $600 \mathrm{~nm}$ and related to dry weight by means of an appropriate calibration curve.

Transport studies. Suspensions of C. albicans in buffer were prewarmed at $37^{\circ} \mathrm{C}$ for $5 \mathrm{~min}$ and then added to give $0.4 \mathrm{mg}$ dry wt ml ${ }^{-1}$ in $10 \mathrm{ml} \mathrm{0.1} \mathrm{M}^{-\mathrm{Na}_{2}} \mathrm{HPO}_{4} /$ citric acid buffer, $\mathrm{pH} 5 \cdot 0$, containing $2 \%(\mathrm{w} / \mathrm{v})$ glucose, the radioactivity labelled peptide under investigation [300 $\mu \mathrm{M}, 0.05$ to $0.1 \mu \mathrm{Ci}_{\mu} \mathrm{mol}^{-1}\left(1.8\right.$ to $\left.3.7 \mathrm{kBq} \mu \mathrm{mol}^{-1}\right)$ ] and inhibitors and unlabelled peptides as required. The flasks were incubated without shaking at $37^{\circ} \mathrm{C}$; $1 \mathrm{ml}$ samples were removed at $1 \mathrm{~min}$ intervals, filtered through glass-fibre discs (Whatman, GF/C) and washed with $10 \mathrm{ml}$ buffer at $4{ }^{\circ} \mathrm{C}$. The filters were dried, scintillation fluid ( $4 \mathrm{~g}$ diphenyloxazole $1^{-1}$ in toluene) was added and the radioactivity was measured using a Packard 3385 scintillation spectrometer.

Peptides. Glycyl[U. $\left.{ }^{14} \mathrm{C}\right]$ phenylalanine $\left(0.21 \mathrm{mCi} \mathrm{mmol}^{-1}, 7.8 \mathrm{MBq} \mathrm{mmol}{ }^{-1}\right)$ was purchased from The Radiochemical Centre, Amersham. Alanyl[U-14 $\left.{ }^{14}\right]$ alanine $\left(0.31 \mathrm{mCi} \mathrm{mmol}^{-1}, 11.5 \mathrm{MBq} \mathrm{mmol}{ }^{-1}\right)$, alanylalanyl[U_-14 $\mathrm{C}^{14}$ alanine $\left(0.30 \mathrm{mCi} \mathrm{mmol}^{-1}, 11.1 \mathrm{MBq} \mathrm{mmol}^{-1}\right)$, alanylaminoethylphosphonate (alafosfalin), alanylaminoethyltetrazole, acetylalanylalanylalanine, acetylalanylglycylalanine, alanylmethoxyvinylglycine and alanyl-2-amino-4-sulphamoylbutyric acid were gifts from Dr P. S. Ringrose, Roche Products Ltd. $\alpha$-Glutamylalanine, $\gamma$-glutamylalanine, $\alpha$-glutamylalanylalanine and $\gamma$-glutamylglycylglycine were purchased from Uniscience, Cambridge; all other peptides were from Sigma. Amino acids were of the $\mathbf{L}$ configuration unless otherwise specified.

Amino acid analysis. Samples for amino acid analysis were prepared from $10 \mathrm{ml}$ (4 $\mathrm{mg}$ dry wt cells) of the incubation mixture after $20 \mathrm{~min}$. The cells were collected by filtering through glass-fibre filters, washed with $10 \mathrm{ml}$ cold $\left(4^{\circ} \mathrm{C}\right)$ buffer and treated with $2 \mathrm{ml} 5 \%(\mathrm{w} / \mathrm{v})$ trichloroacetic acid for $30 \mathrm{~min}$ at $0{ }^{\circ} \mathrm{C}$. The precipitate was sedimented by centrifuging $(1000 \mathrm{~g}$ for $5 \mathrm{~min})$ and washed with trichloroacetic acid. The soluble extract was filtered to remove any residual debris and extracted five times with an equal volume of diethyl ether. The aqueous phase was evaporated to dryness and the residue was resuspended in $0.02 \mathrm{M}-\mathrm{HCl}$. Samples $(0.1 \mathrm{ml}$, equivalent to $1 \mathrm{mg}$ dry wt cells) were applied to a bench model amino acid analyser (Locarte, London) and eluted with sodium citrate buffers. The peaks were identified and calibrated against a standard amino acid mixture.

Assay of effuxed material. The method of Woodward \& Cirillo (1977) was used to study the material effluxed from cells. Cultures were incubated with radioactively labelled peptide for $20 \mathrm{~min}$. The cells were collected by filtration, washed and resuspended at the same density in buffer containing $2 \%(\mathrm{w} / \mathrm{v})$ glucose. Samples $(1 \mathrm{ml})$ were taken at intervals to determine the radioactivity incorporated into whole cells. The filtrate from these samples was adjusted to $\mathrm{pH} 1.2$ with conc. $\mathrm{HCl}$. An equal volume of amyl alcohol was added, the tubes were vigorously mixed for $15 \mathrm{~s}$ and the phases were separated by centrifugation $(1000 \mathrm{~g}$ for $10 \mathrm{~min})$. The radioactivity in each phase was measured in $0.1 \mathrm{ml}$ samples using Triton X-100/toluene scintillant.

\section{RESULTS}

Gly-Phe, Ala-Ala [(Ala $)_{2}$ ] and Ala-Ala-Ala [(Ala $)_{3}$ ] were transported by C. albicans from $300 \mu \mathrm{M}$ solution at rates of 1.5 to 3,3 to 7 and 5 to $9 \mathrm{nmol} \mathrm{min}^{-1} \mathrm{mg}^{-1}$, respectively. Transport of the dipeptides was energy-dependent as it was totally inhibited by $0 \cdot 1 \mathrm{~mm}$-sodium azide, $20 \mu \mathrm{M}$-carbonyl cyanide $m$-chlorophenylhydrazone and $2.0 \mathrm{~mm}$-sodium arsenate in separate experiments. The uptake of (Ala $)_{2}$ and Gly-Phe was maximal at $\mathrm{pH} 4.5$ and showed half-maximal rates at $\mathrm{pH} 3.8$ and 6.0. The uptake of Gly-Phe was temperature-dependent between 20 and $40^{\circ} \mathrm{C}$ with a $Q_{10}$ value of $2 \cdot 7$.

Double reciprocal plots of the initial rates of uptake over the concentration range 30 to $1000 \mu \mathrm{M}$ gave $K_{\mathrm{m}}$ values of $350 \mu \mathrm{M}$ for Gly-Phe, $250 \mu \mathrm{M}$ for (Ala $)_{2}$ and $115 \mu \mathrm{M}$ for (Ala) . $_{3}$

\section{Competition by other peptides}

Decrease of the initial rate of uptake of radioactively labelled Gly-Phe, (Ala) ${ }_{2}$ and (Ala) 3 by competing peptides was used to determine the specificity of the permeases. Table 1 shows the percentage inhibition obtained with a variety of di- and tripeptides. Peptides containing hydrophobic or neutral amino acids, that is (Ala) $)_{2}$, Ala-Leu, Leu-Ala, (Leu) $)_{2}$ and (Leu) ${ }_{3}$, were more effective inhibitors than those containing acidic residues, Glu-Glu and Glu-Ala. When glycine replaced alanine in a peptide, as in (Gly $)_{2}$ and Gly-Leu, the ability to compete 
Table 1. Effect of amino acids and peptides on the rate of transport of radioactive peptides

Candida albicans $\left(0.4 \mathrm{mg} \mathrm{ml}^{-1}\right)$ was incubated at $37^{\circ} \mathrm{C}$ in $0.1 \mathrm{M}-\mathrm{Na}_{2} \mathrm{HPO}_{4} /$ citric acid buffer, pH $5 \cdot 0$, containing $2 \%(\mathrm{w} / \mathrm{v})$ glucose, radioactive peptide $(0.3 \mathrm{~mm})$ and unlabelled amino acids or peptides $(3.0 \mathrm{~mm})$ as competitors. Results are expressed as percentage inhibition of the initial rate of uptake of the radioactive peptide.

Percentage inhibition

\begin{tabular}{|c|c|c|c|}
\hline Competitor & Gly-[$\left[{ }^{14} \mathrm{C}\right]$ Phe & Ala- $\left[{ }^{14} \mathrm{C}\right] \mathrm{Ala}$ & Ala-Ala- $\left[{ }^{14} \mathrm{C}\right] \mathrm{Ala}$ \\
\hline Gly-Phe & (83) & 21 & 38 \\
\hline Gly-Leu & 69 & 54 & 36 \\
\hline Gly-Gly & 26 & 6 & 0 \\
\hline Ala-Ala & 85 & (83) & 86 \\
\hline Ala-Leu & - & 91 & 100 \\
\hline Leu-Ala & - & 92 & 94 \\
\hline Leu-Leu & - & 100 & - \\
\hline Glu-Glu & 52 & 18 & - \\
\hline$(\mathrm{Ala})_{3}$ & 81 & 59 & (85) \\
\hline$(\text { Gly })_{3}$ & 6 & 0 & 0 \\
\hline$(\mathrm{Leu})_{3}$ & - & 100 & 100 \\
\hline Gly & 0 & - & - \\
\hline Phe & 0 & - & - \\
\hline Ala & - & 0 & 0 \\
\hline
\end{tabular}

Table 2. Effect of peptides on the rate of transport of alanyl peptides For experimental conditions, see legend to Table 1.

Competitor*
L-Ala-D-Ala
D-Ala-L-Ala
D-Ala-D-Ala
$\alpha$-Glu-Ala
$\gamma$-Glu-Ala
$\alpha$-Glu-Ala-Ala
$\gamma$-Glu-Gly-Gly
$\beta$-Ala-Ala

Ala-Ala-phosphonate

Ala-Ala-tetrazole

Ala-MVG

Ala-ASB

Ac-Ala-Ala-Ala Ac-Ala-Gly-Ala
Percentage inhibition

$\begin{array}{cc}\left.\text { Ala-[ }{ }^{14} \mathrm{C}\right] \text { Ala } & \left.\text { Ala-Ala-[ }{ }^{14} \mathrm{C}\right] \text { Ala } \\ 0 & - \\ 0 & - \\ 0 & - \\ 65 & 59 \\ 4 & 66 \\ 52 & 10 \\ 0 & - \\ 0 & 39 \\ 48 & 100 \\ 100 & - \\ 76 & 36 \\ 67 & 0 \\ - & 0\end{array}$

-, Not tested.

* Abbreviations: MVG, methoxyvinylglycine; ASB, 2-amino-4-sulphamoylbutyric acid; Ac, acetyl.

was diminished. There was no decrease in peptide uptake in the presence of the component amino acids.

Further competition experiments were performed with modified peptides (Table 2). Dipeptides containing one or more D-residues, L-Ala-D-Ala, D-Ala-L-Ala and D-Ala-D-Ala, were not inhibitory. $\beta$-Ala-Ala, $\gamma$-Glu-Ala and $\gamma$-Glu-Gly-Gly were much less effective inhibitors than the corresponding $\alpha$-linked peptides. Acetylated peptides had no inhibitory capacity, but modified (Ala) ${ }_{2}$ containing a tetrazole or a phosphonate group in place of the carboxyl group did compete for uptake. Peptides containing the abnormal amino acid residues methoxyvinylglycine and 2-amino-4-sulphamoylbutyric acid coupled to alanine were also effective inhibitors of (Ala) $)_{2}$ and (Ala $)_{3}$ transport. 

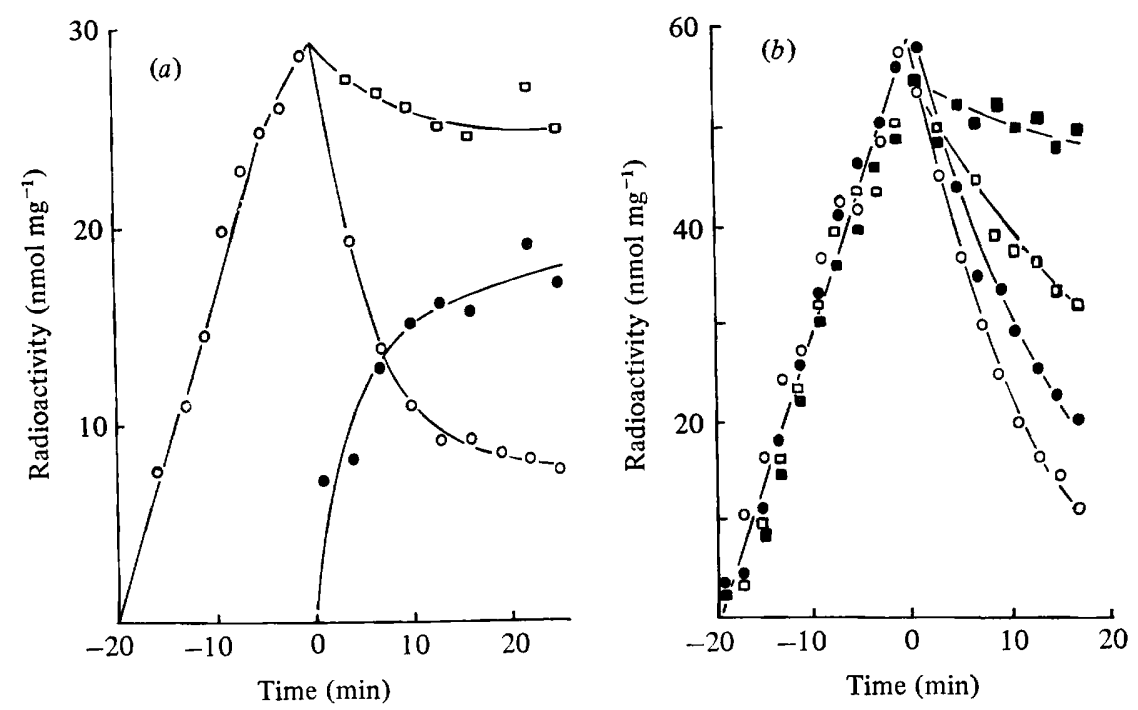

Fig. 1. Uptake and efflux of radioactive label from Gly-Phe. Candida albicans $\left(0.4 \mathrm{mg} \mathrm{ml} \mathrm{m}^{-1}\right)$ was incubated at $37^{\circ} \mathrm{C}$ in $0.1 \mathrm{M}-\mathrm{Na}_{2} \mathrm{HPO}_{4} /$ citric acid buffer, $\mathrm{pH} 5.0$, with $2 \%(\mathrm{w} / \mathrm{v})$ glucose and Gly-[U-14 C]Phe $\left(0.3 \mathrm{~mm}, 0 \cdot 105 \mu \mathrm{Ci} \mu \mathrm{mol}^{-1}\right)$. After $20 \mathrm{~min}$ the cells were collected by filtration, washed and resuspended at the same density in buffer containing $2 \%(\mathrm{w} / \mathrm{v})$ glucose (time 0 ). (a) Cells were incubated at $37^{\circ} \mathrm{C}$ and the radioactivity in whole cells $(O)$ and in the supernatant fluid (O) was measured and the total amounts were calculated ( $\square$ ). (b) After resuspension the cells were incubated at various temperatures and the radioactivity in whole cells was measured: $0{ }^{\circ} \mathrm{C}$ (回), $18^{\circ} \mathrm{C}(\square), 27^{\circ} \mathrm{C}(O)$ or $37^{\circ} \mathrm{C}(O)$. In both $(a)$ and $(b)$, results are expressed as nmol (mg dry wt cells $)^{-1}$ based on the original specific activity of the peptide.

\section{Accumulation and loss of amino acids after peptide transport}

Incubation of $C$. albicans with (Ala) $)_{2}$ resulted in the expansion of the cytoplasmic (trichloroacetic-soluble) pool of alanine only. Uptake of Gly-Phe by C. albicans, however, was accompanied by an increase in the concentration of the intact peptide as well as in the concentrations of glycine and phenylalanine, suggesting that peptidase activity is not required for transport. Alafosfalin was accumulated in C. albicans as the intact peptide and there was no increase in the alanine pool. This contrasts with results from $E$. coli in which this peptide mimetic was transported and then hydrolysed to release the active moiety and alanine (Atherton et al., 1979). The variation in the susceptibility of peptides to hydrolysis in $C$. albicans was also shown with tripeptides. Alanine, phenylalanine and glycine were found in the amino acid pools after cells had been incubated with Ala-Phe-Gly, whereas Gly-Gly, as well as free glycine and phenylalanine, accumulated after transport of PheGly-Gly. Glycyl peptides are also less susceptible to hydrolysis in Staphylococcus aureus (Perry \& Abraham, 1979).

When cells that had accumulated radioactive phenylalanine from Gly[U- $\left.{ }^{14} \mathrm{C}\right] \mathrm{Phe}$ were resuspended in fresh buffer there was a time-dependent loss of radioactivity from whole cells which corresponded with an increase of the radioactivity in the supernatant fluid (Fig. 1a). The efflux of material was temperature-dependent (Fig. $1 b$ ) and was inhibited by sodium azide $(0.6 \mathrm{~mm})$ but not by sodium arsenate (experiment performed in citrate buffer). Amino acid analysis of the supernatant fluid failed to reveal the presence of ninhydrinpositive material. The effluxed radioactive material was partitioned between acidified buffer and amyl alcohol and the radioactivity preferentially separated into the organic layer. Phenylalanine and glycine were recovered from the aqueous phase under similar conditions. This suggests that it is a deaminated product, which is not ionized at $\mathrm{pH} 1 \cdot 2$, which is being lost from the cells. 


\section{DISCUSSION}

A variety of di- and tripeptides share a common permease in C. albicans which is energydependent and has a requirement for $L$-amino acid residues, an $\alpha$-linkage between residues and a free amino terminus. Peptides containing abnormal amino acid side-chains are also carried by this system.

The results are in agreement with those for peptide transport in $S$. cerevisiae which has a general peptide permease for di- and tripeptides. However, Logan et al. (1979) reported that $(\mathrm{Met})_{2}$ did not compete with radioactively labelled (Met) ${ }_{3}$ and they concluded that di- and tripeptides did not share a permease in C. albicans WD 18-4. Becker \& Naider (1977) reported a similar lack of inhibition of labelled (Met) $)_{3}$ uptake by (Met) ${ }_{2}$ in $S$. cerevisiae and it may be that di- and/or trimethionine is not a substrate for the general peptide permease in yeast, or that trimethionine is transported by an additional peptide permease with a more limited specificity. Such a multiplicity of permeases has been found in $E$. coli, in which certain tripeptides, including trimethionine, are substrates for an additional oligopeptide permease (Barak \& Gilvarg, 1975).

Another difference between the results reported here and those of other studies concerns the transport of acetylated peptides. Ac(Ala $)_{3}$ did not reduce the rate of transport of (Ala) $)_{3}$ in $C$. albicans 6406, whereas $\mathrm{Ac}(\mathrm{Met})_{3}$ inhibited (Met) $)_{3}$ transport in C. albicans WD 18-4 (Logan et al., 1979). Such a discrepancy could also be explained if (Met) ${ }_{3}$ was not transported by the general peptide permease.

Peptide uptake in $E$. coli is accompanied by a simultaneous exodus of amino acids which have been accumulated in the pool (Payne $\&$ Bell, 1979). Such an exodus does not occur in yeasts (Kotyk, 1972), but metabolized products, such as oxo-acids and fusel oil derivatives, can be lost after amino acid uptake (Woodward \& Cirillo, 1977). The loss of radioactively labelled material from whole cells and the appearance in the supernatant fluid of radioactively labelled material which partitions into the organic layer suggests that such an exodus occurs in C. albicans after peptide transport. A similar process was postulated to accompany peptide transport in $S$. cerevisiae (Nisbet \& Payne, 1979a).

Much of the interest in peptide transport has been prompted by considerations of antibiotic transport and the permeases of $C$. albicans may also prove exploitable in this respect. However, the extent of strain variation and the exact specificity of the permeases will need to be determined. The isolation of mutants lacking peptide permeases, similar to those of S. cerevisiae resistant to bacilysin and ethionylalanine (Nisbet \& Payne, 1979b; Marder et al., 1978), should prove advantageous in this respect.

I acknowledge the receipt of an SRC-CASE studentship in cooperation with Roche Products Ltd. I am very grateful for the help and advice of Professor E. F. Gale and Dr P. S. Ringrose during the course of this work.

\section{REFERENCES}

Allen, J. G., Atherton, F. R., Hall, M. J., Hassall, C. H., Holmes, S. W., Nisbet, L. J. \& Ringrose, P. S. (1978). Phosphonopeptides, a new class of synthetic antibacterial agents. Nature, London 272, 56-58.

atherton, F. R., Hall, M. J., Hassall, C. H., LAmbert, R. W., Lloyd, W. J. \& Ringrose, P. S. (1979). Phosphonopeptides as antibacterial agents: mechanism of action of Alaphosphin. Antimicrobial Agents and Chemotherapy 15, 696-705.

BaraK, Z. \& Gilvarg, C. (1975). Specialized pep- tide transport system in Escherichia coli. Journal of Bacteriology 122, 1200-1207.

Becker, J. M. \& NAIDer, F. (1977). Peptide transport in yeast : uptake of radioactive trimethionine in Saccharomyces cerevisiae. Archives of Biochemistry and Biophysics 178, 245255.

Kenig, M., Vandamme, E. \& Abraham, E. P. (1976). The mode of action of bacilysin and anticapsin and biochemical properties of bacilysin-resistant mutants. Journal of General Microbiology 94, 46-54. 
KoTYK, A. (1972). Transport of non-electrolytes in yeast. Biochemical Journal 127, 51P-52P.

Levine, E. M. \& Simmonds, S. (1962). Further studies on metabolite uptake by serine-glycine auxotrophs of Escherichia coli. Journal of Biological Chemistry 237, 3718-3724.

Lichliter, W. D., NAIDER, F. \& Becker, J. M. (1976). Basis of the design of anticandidal agents from studies of peptide utilization in Candida albicans. Antimicrobial Agents and Chemotherapy 10, 483-490.

LogaN, D. A., BeCKer, J. M. \& NAIDER, F. (1979). Peptide transport in Candida albicans. Journal of General Microbiology 114, 179-186.

MARdER, R., BeCKer, J. M. \& NAIDER, F. (1977). Peptide transport in yeast: utilization of leucineand lysine-containing peptides by Saccharomyces cerevisiae. Journal of Bacteriology 131, 906-916.

MARder, R., Rose, B., Becker, J. M. \& NAIDER, F. (1978). Isolation of a peptide transport-deficient mutant of yeast. Journal of Bacteriology 136, 1174-1177.

Nisbet, T. M. \& Payne, J. W. (1979a). Peptide uptake in Saccharomyces cerevisiae: characteristics of transport system shared by di- and tripeptides. Journal of General Microbiology 115, 127-133.

Nisbet, T. M. \& PAyne, J. W. (1979 b). Specificity of peptide uptake in Saccharomyces cerevisiae, and isolation of a bacilysin-resistant, peptide-transport-deficient mutant. FEMS Microbiology Letters 6, 193-196.

PAYNe, J. W. (1972a). Effects of $N$-methyl peptide bonds on peptide utilization by Escherichia coli. Journal of General Microbiology 71, 259-265.

PAYNE, J. W. (1972 b). Mechanisms of bacterial peptide transport. In Peptide Transport in Bacteria and Mammalian Gut, ClBA Foundation Symposium, pp. 17-32. Edited by K. Elliott \& M. O'Connor. Amsterdam: Associated Scientific Publishers.

Payne, J. W. (1974). Peptide transport in Escherichia coli: permease specificity towards terminal amino group substituents. Journal of General Microbiology 80, 269-276.

Payne, J. W. \& Bell, G. (1979). Direct determination of the properties of peptide transport systems in Escherichia coli, using a fluorescent-labeling procedure. Journal of Bacteriology 137, 447-455.

Payne, J. W. \& Gilvarg, G. (1968a). The role of the terminal carboxyl group in peptide transport in Escherichia coli. Journal of Biological Chemistry 243, 335-340.

Payne, J. W. \& Gilvarg, G. (1968b). Size restriction on peptide utilization in Escherichia coli. Journal of Biological Chemistry 243, 6291-6299.

Payne, J. W. \& Gilvarg, G. (1978). Transport of peptides in bacteria. In Bacterial Transport, pp. 325-384. Edited by B. P. Rosen. New York and Basel: Marcel Dekker.

Perry, D. \& Abraham, E. P. (1979). Transport and metabolism of bacilysin and other peptides by suspensions of Staphylococcus aureus. Journal of General Microbiology 115, 213-221.

Wolfinbarger, L. \& Marzluf, G. A. (1974). Peptide utilization by amino acid auxotrophs of Neurospora crassa. Journal of Bacteriology 119, 371-378.

Woodward, J. R. \& Cirillo, V. P. (1977). Amino acid transport and metabolism in nitrogen-starved cells of Saccharomyces cerevisiae. Journal of Bacteriology 130, 714-723. 